\title{
PENGARUH LAMA BLANCHING UAP TERHADAP KANDUNGAN KADAR $\beta$ - KAROTEN, KADAR AIR, DAYA SERAP AIR, DENSITAS KAMBA DAN RENDEMEN TEPUNG UBI JALAR KUNING (Ipomea batatas L.)
}

\author{
Effect Of Length Blanching Steam on Betakaroten Contens, Water Contens, Water \\ Absorption, Density Kamba And Rendemen Of Yellow Sweet Potato Flour (Ipomea \\ Batatas L.)
}

\author{
Rika Wahyu Damayanti, I Komang Suwita \\ Jurusan Gizi Politeknik Kesehatan Kemenkes Malang \\ Jl. Besar Ijen No. 77 C Malang 65112 \\ Email : ksuwita@gmail.com
}

\begin{abstract}
ABSTRAK
Penelitian ini bertujuan untuk mengetahui pengaruh lama metode blanching uap terhadap kandungan kadar $\beta$-karoten, kadar air, daya serap ,densitas kamba dan rendemen tepung ubi jalar kuning (Ipomeabatatas l.). Teknik pengolahan ubi jalar kuning dengan cara blanching memberikan pengaruh yang nyata terhadap kadar $\beta$ Karoten, kadar air, daya serap air,densitas kamba dan rendemen. Kadar $\beta$-Karoten tertinggi ada pada perlakuan blaching selama 20 menit $(1,1695 \mu \mathrm{g} / \mathrm{g})$, Kadar air tepung ubi jalar kuning tertinggi terdapat pada taraf perlakuan tanpa blanching selama 20 menit $(9,66 \%)$, Daya serap air tepung ubi jalar kuning tertinggi terdapat pada taraf perlakuan blanching dengan waktu 20 menit (2,90 g), Rendemen tepung ubi jalar kuning tertinggi terdapat pada taraf perlakuan blanching dengan waktu 20 menit $(59,9 \%)$. Disarankan untuk penelitian yang akan datang yaitu memperhatikan varietas ubi jalar kuning sesuai dengan varietas sekitar.
\end{abstract}

Kata Kunci : Ubi jalar Kuning, Blanching Uap, Kadar $\beta$-Karoten, rendemen

\section{ABSTRACT}

This study aims to determine the effect of the old steam blanching method on the content of $\beta$-carotene content, moisture content, absorbency, cage density and yield of yellow sweet potato flour (Ipomeabatatasl.). The yellow sweet potato processing technique with long steam blanching has a significant effect on $\beta$-carotene content, moisture content, water absorption, kamba density and yield. The highest $\beta$-carotene content was found in the 20-minute blaching treatment $(1.1695 \mu \mathrm{g} / \mathrm{g})$, the highest water content of yellow sweet potato flour was found at the treatment level without blanching for 20 minutes (9.66\%), water absorption of sweet potato flour the highest yellow was found at the level of blanching treatment with a time of 20 minutes $(2.90 \mathrm{~g})$. The highest yield $o$ f yellow sweet potato flour was found in the level of blanching with a time of 20 minutes (59.9\%). It is recommended for future research to pay attention to the yellow sweet potato varieties according to the surrounding varieties.

Keywords : Yellow Sweet Potato Flour, Steam Blanching, Betakaroten Contens, yield. 


\section{PENDAHULUAN}

Kekurangan Vitamin A (KVA) masih menjadi salah satu masalah gizi yang ada di dunia. Di Indonesia, Riskesdas (2013) melaporkan bahwa prevalensi xeropthalmia pada balita $0,13 \%$ dan $14,6 \%$ mempunyai kadar serum vitamin A (retinol) dibawah standart tingkat kecukupan yang telah ditetapkan oleh WHO yaitu kurang dari $20 \mu \mathrm{g} / \mathrm{dl}$. Strategi pencegahan dan penanggulangan

KVA selama ini dilakukan dengan distribusi kapsul vitamin A. Upaya lain yang telah dilakukan pemerintah adalah dengan fortifikasi vitamin A pada bahan makanan seperti minyak goreng dan tepung terigu. Penyediaan bahan makanan lokal dengan harga yang relatif murah, mudah didapat, mudah disimpan dan praktis penggunaannya perlu diupayakan untuk mengurangi kejadian KVA.

Ubi jalar termasuk jenis umbiumbian sumber karbohidrat yang mempunyai potensi untuk dikembangkan sebagai bahan pangan pengganti beras (bahan baku industri pangan maupun non pangan). Kelebihan dari ubi jalar yang berwarna yaitu mengandung antioksidan yang kuat untuk menetralisir keganasan radikal bebas penyebab penuaan dini dan pencetus aneka penyakit degeneratif seperti kanker dan jantung (Reifa, 2005).

Ubi jalar berdaging kuning merupakan sumber vitamin $\mathrm{C}$ dan $\beta$ Karoten (provitamin A) yang mengandung $0,2503 \mathrm{mg} / 100$ gram $\beta$ Karoten tinggi dibandingkan dengan ubi jalar putih dan ubi jalar ungu yang masing-masing mengandung 0,0539 mg dan 0,1244 mg $\beta$ - Karoten (Kemal, dkk. 2013). Namun tidak bisa dipungkiri bahwa kandungan terbesar $\beta$ - Karoten berada pada sayuran wortel, yaitu 754 ug dalam 100 gram bahan makanan yang setara dengan $0,754 \mathrm{mg}(1 \mathrm{ug}=0,001 \mathrm{mg})$, namun dalam segi produksi wortel masih jauh dibawah produksi ubi jalar yaitu 24.099 ton dengan area panen seluas 3.190 ha (BPS, 2015) sehingga sebagai pemanfaatan pangan lokal sangat mudah dijumpai ubi jalar sebagai bahan utama atau bahan tambahan yang mudah diolah.

Sebelum ubi jalar kuning melalui proses penepungan, terdapat perlakuan pendahuluan yang disebut dengan blanching. Melakukan blanching pada bahan makanan yang akan ditepungkan berguna untuk menginaktivasikan enzim dalam bahan makanan. Namun, proes blanching dengan suhu yang tinggi dapat menurunkan kadar $\beta$-Karoten. Ningrum 
(1999) dalam Honestin (2007) menyatakan bahwa karotenoid belum mengalami kerusakan oleh pemanasan pada suhu $60^{\circ} \mathrm{C}$ dan jumlahnya menurun secara drastis pada suhu $180-220^{\circ} \mathrm{C}$.

Proses blanching memiliki variasi suhu dan waktu yang berbeda. Menurut Estiasih dan Ahmadi (2009) suhu blanching berada pada kisaran $75-95^{\circ} \mathrm{C}$, dan pada blanching uap kehilangan komponen bahan pangan akibat proses pelarutan dapat dihindari. Dalam hal ini dikatakan bahwa menggunakan metode blanching uap dapat terjadi sedikit penurunan komponen bahan pangan. Oleh karena itu, diperlukan kajian tentang pengaruh lama blanching uap terhadap kandungan kadar $\beta$-karoten, kadar air, daya serap air, densitas kamba dan rendemen tepung ubi jalar kuning (Ipomea batatas $L$.).

\section{METODE PENELITIAN}

Penelitian dilaksanakan pada bulan Januari-April 2016, bertempat di Laboratorium Ilmu Teknologi Pangan, Laboratorium Kimia Poltekkes Kemenkes Malang, dan Laboratorium Akafarma Putra Indonesia Malang.

Penelitian ini merupakan jenis penelitian Experimental dengan desain penelitian Rancangan Acak Lengkap
(RAL). Menurut A, Asgar (2006), suhu terbaik pembuatan tepung wortel adalah $85^{\circ} \mathrm{C}$ dengan lama waktu 10 menit, sehingga pada penelitian ini dilakukan blanching uap dengan variasi lama waktu perlakuan yaitu : P0 (0 menit), P1 (5 menit), P2 (10 menit), P3 (15 menit), dan P4 (20 menit). Masing-masing taraf perlakuan dilakukan 3 kali pengulangan.

\section{Bahan dan Alat}

Bahan yang digunakan untuk pembuatan tepung ubi jalar adalah ubi jalar kuning.

Alat untuk pembuatan tepung ubi jalar kuning yaitu: timbangan triple beam, baskom, risopan, termometer, kompor dan gas LPJ, oven, ayakan tepung (80 mesh), blender tepung dan loyang.

\section{Pengujian}

Pengujian yang dilakukan meliputi: rendemen tepung ubi jalar kuning (Anggraini, 2013), kadar B-karoten dengan metode spektofotometri (AOAC (dalam Puranti 2012), kadar air dengan metode pengeringan oven (AOAC, 1995, daya serap air (Apriyantono, 1989), dan densitas kamba (Muchtadi, 1992).

Pengolahan data nilai gizi dan sifat fungsional tepung ubi jalar kuning dilakukan dengan tujuan untuk 
mengetahui ada atau tidaknya pengaruh lama blanching terhadap gizi kadar $\beta$ karoten, kadar air, dan sifat fungsional tepung ubi jalar kuning. Uji analisis statistik dilakukan dengan menggunakan uji One Way Anova pada tingkat kepercayaan 95\%, dan jika menunjukan pengaruh yang signifikan maka akan dilanjutkan dengan uji Duncan Multiple Range Test (DMRT.

\section{HASIL DAN PEMBAHASAN}

Karakteristik Produk Tepung Ubi Jalar Kuning.

Tepung ubi jalar dibuat dengan metode blanching uap dengan perbedaaan waktu 5 menit dan kelipatannya hingga mencapai waktu 20 menit. Pada penelitian ini, pemilihan metode pembuatan tepung ubi jalar kuning diawali dengan proses blanching yang merupakan variabel dari penelitian yang selanjutnya mendapatkan perlakukan pengeringan untuk menjadikan tepung ubi jalar kuning.

Variasi warna tepung ubi jalar kuning yang dihasilkan dipengaruhi oleh varietas ubi jalar dan proses pencoklatan (browning) saat dilakukan pengupasan. Kerusakan warna pada produk ubi jalar (browning) disebabkan oleh adanya aktivitas enzim catechol oksidase jika terdapat tanin atau zat semacam tanin.
Proses pengeringan yang dilakukan pada pembuatan tepung ubi jalar bertujuan untuk menurunkan jumlah air yang dikandung oleh bahan mentah. Kadar air merupakan salah satu parameter yang cukup penting pada produk tepung karena berkaitan dengan mutu. Rata-rata kadar air tepung ubi jalar kuning yang diperoleh berkisar antara 8,56-9,66\%. Kondisi ini sudah memnuhi syarat kadar air yang aman untuk tepung yaitu $<14 \%$ sehingga dapat mencegah pertumbuhan kapang (Winarno dan Jenie, 1974 dalam Honestin 2007). Hal tersebut juga diperjelas dalam SNI tepung tapioka nomor 01-37291995 bahwa kadar air tepung tapioca maksimal $13 \%$. Visualisasi tepung ubi jalar kuning, sebagaimana disajikan pada Tabel 1.

Tabel 1. Visualisai Tepung Ubi Jalar Kuning

\begin{tabular}{|c|c|c|}
\hline $\begin{array}{c}\text { Tepung Ubi Jalar } \\
\text { Kuning }\end{array}$ & $\begin{array}{l}\text { Taraf } \\
\text { Perlakuan }\end{array}$ & Warna \\
\hline & $\begin{array}{l}\text { P0 : Tanpa } \\
\text { Blanching }\end{array}$ & $\begin{array}{c}\text { Kuning } \\
\text { Kecoklat } \\
\text { an }\end{array}$ \\
\hline & $\begin{array}{c}\text { P1 } \\
\text { Blanching } \\
\text { Uap } \\
\text { waktu 5 } \\
\text { menit }\end{array}$ & $\begin{array}{c}\text { Kuning } \\
\text { Kecoklat } \\
\text { an }\end{array}$ \\
\hline & $\begin{array}{c}\mathrm{P} 2 \\
\text { Blanching } \\
\text { Uap }, \\
\text { waktu } 10 \\
\text { menit }\end{array}$ & $\begin{array}{c}\text { Kuning } \\
\text { Kecoklat } \\
\text { an }\end{array}$ \\
\hline
\end{tabular}




\begin{tabular}{|l|c|c|}
\hline & $\begin{array}{c}\text { P3 } \\
\text { Blanching } \\
\text { Uap , } \\
\text { waktu 15 }\end{array}$ & $\begin{array}{c}\text { Kuning } \\
\text { Muda }\end{array}$ \\
\hline & $\begin{array}{c}\text { P4 } \\
\text { Blanching } \\
\text { Uap, } \\
\text { waktu 20 }\end{array}$ & $\begin{array}{c}\text { Kuning } \\
\text { Muda }\end{array}$ \\
\hline
\end{tabular}

\section{Beta Karoten}

Kadar beta karoten tepung ubi jalar kuning berkisar antara 0,0067 $1.1695 \mu \mathrm{g} / \mathrm{g}$.

Kadar beta karoten tepung ubi jalar kuning tertinggi terdapat pada taraf perlakuan blanching uap dengan waktu 20 menit yaitu

$1.1695 \mu \mathrm{g} / \mathrm{g}$, sedangkan beta karoten terendah terdapat pada taraf perlakuan tanpa blanching

yaitu $0,0067 \mu \mathrm{g} / \mathrm{g}, \quad$ sebagaimana disajikan pada

Gambar 1

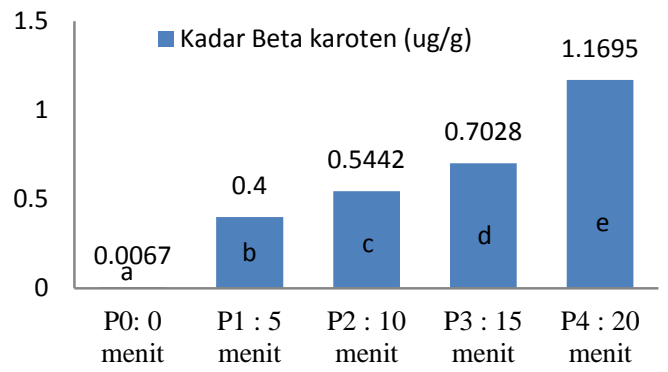

Keterangan: Notasi yang berbeda menunjukkan adanya perbedaan yang signifikan $(\alpha=0,05)$
Gambar 1. Kadar Beta Karoten Tepung Ubi Jalar Kuning dengan blanching uap

Gambar 1 menunjukkan bahwa perlakuan metode blanching semakin lama waktu blanching yang digunakan maka kadar beta karoten cenderung semakin meningkat. Hasil analisis statistik OneWay Anova pada tingkat kepercayaan 95\% menunjukkan bahwa taraf perlakuan metode blanching berpengauh signifikan $(\mathrm{p}=0,000)$ terhadap kadar beta karoten tepung ubi jalar kuning yang dihasilkan. Uji lanjut analisis statistik Duncan Multiple Range Test bahwa kadar beta karoten tepung ubi jalar kuning pada masing-masing taraf perlakuan metode blanching (P0, P1, P2, P3 dan P4) menunjukkan adanya perberbedaan yang signifikan.

Taraf perlakuan blanching uap selama 20 menit menghasilkan kadar beta karoten yang cukup tinggi. Hal ini disebabkan karena salah satu fungsi blanching adalah menginaktifkan enzim, sehingga pada waktu pemanasan dengan waktu 20 menit enzim yang terdapat dalam ubi jalar kuning dapat mengkatalis reaksi oksidasi terhadap senyawa fenol yang mengakibatkan pembentukan warna coklat yang tidak dikehendaki karena merusak penampilan 
produk. Warna yang dihasilkan adalah kuning muda (kuning) adalah karotenoid. Karotenoid merupakan kelompok pigmen yang bewarna kuning, oranye, merah oranye (Winarno, 1997). Terlihat pada hasil pengujian dimana taraf perlakuan dengan blanching uap selama 20 menit menghasilkan warna kuning yang semakin tajam sehingga kadar beta karoten tertinggi ada pada taraf perlakuan tersebut yaitu $1.1695 \mu \mathrm{g} / \mathrm{g}$.

\section{Kadar Air}

Kadar air tepung ubi jalar kuning berkisar antara 8,56 - 9,66\%. Kadar air tepung ubi jalar kuning tertinggi terdapat pada taraf perlakuan tanpa blanching uap yaitu 9,66\%, sedangkan kadar air terendah terdapat pada taraf perlakuan blanching uap dengan waktu 20 menit yaitu $8,56 \%$, sebagaimana disajikan pada Gambar 2.

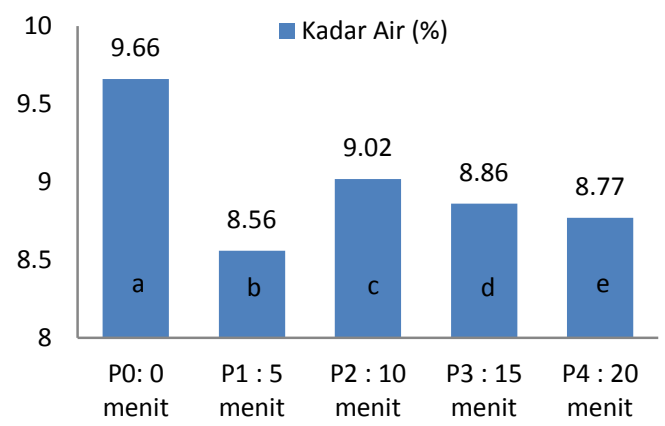

Keterangan: Notasi yang berbeda menunjukkan adanya perbedaan yang signifikan $(\alpha=0,05)$
Gambar 2. Kadar Air Tepung Ubi Jalar Kuning

Pada Gambar 2 menunjukkan bahwa perlakuan metode blanching uap mempengaruhi kadar air tepung ubi jalar kuning. Hasil analisis statistik One- Way Anova pada tingkat kepercayaan 95\% menunjukkan bahwa taraf perlakuan metode blanching berpengauh signifikan $\quad(\mathrm{p}=0,000)$ terhadap kadar air tepung ubi jalar kuning. Lebih lanjut, analisis statistik Duncan Multiple Range Test menunjukkan bahwa kadar air tepung ubi jalar kuning pada masing-masing taraf perlakuan metode blanching ( $\mathrm{P} 0, \mathrm{P} 1, \mathrm{P} 2$, P3 dan P4) menunjukkan adanya perberbedaan yang signifikan.

Berdasarkan SNI tepung tapioka nomor 01-3729-2006 menunjukkan bahwa kadar air tepung maksimal 13\%, hal ini menunjukkan bahwa kadar air tepung ubi jalar kuning telah memenuhi syarat mutu tepung dan mempunyai kadar air leih rendah. Menurut Winarno dan Jenie (1974) menjelaskan bawah hasil tersebut sudah memenuhi syarat kadar air yang aman untuk tepung yaitu $<14 \%$ sehingga dapat mencegah pertumbuhan kapang.

Taraf perlakuan blanching uap menghasilkan kadar air tepung yang 
relatif rendah dibandingkan dengan yang menyebutkan bahwa kenaikan kadar perlakuan metode dengan blanching air. air mencapai angka 7\% dikarenakan Hal ini disesbabkan uap air lebih mudah peletakan sampel pada saat pengeringan masuk kedalam jaringan ubi jalar kuning tipe rak kurang merata mendapatkan untuk merusak jaringan tersebut, kemudia panas dan tumpukan pada pengering rak pori-pori ubi jalar kuning akan terbuka terlalu banyak.

lebar dan megurangi daya absorbs

Perlakuan tepung ubi jalar terhadap air sehingga sebagian air dalam ubi jalar kuning berkurang (Honestin 2007). Pada saat pengeringan dengahn suhu $70^{\circ} \mathrm{C}$, massa air akan lebih mudah menguap dan menghasilkan kadar air yang lebih rendah. Menurut WInarno, dkk. (1980), uap air dapat mengeluarkan sebagian air yang terikat di dalam bahan dan meningkatkan peremeabilitas jaringan bahan, sehingga bahan yang diblanching uap akan cenderung lebih kering dan memiliki kadar air yang rendah.

Pada Gambar 2. menunjukkan kadar air yang meningkat pada taraf perlakuan blaching uap selama 10 menit yaitu $9,02 \%$. Namun bila dilihat dari data keseluruhan kadar air setiap perlakuan sudah mengalami penurunan. Kadar air yang diperoleh pada hasil dari penelitian relatif lebih rendah bila dibandingkan dengan kadar air bahan yang sejenis yaitu tepung tapioka sebesar maksimal 13\%. Sejalan dengan hasil penelitian Septiani, D. dkk 2015

\section{Daya Serap Air}

Daya serap air tepung ubi jalar kuning berkisar antara 2,21 - 2,90 g. Daya serap air tepung ubi jalar kuning tertinggi terdapat pada taraf perlakuan blanching uap dengan waktu 20 menit yaitu 2,90 g, sedangkan daya serap air terendah terdapat pada taraf perlakuan blanching uap dengan waktu 5 menit yaitu 2,21 g. Untuk daya serap air tepung ubi jalar kuning disajikan pada Gambar 3. 


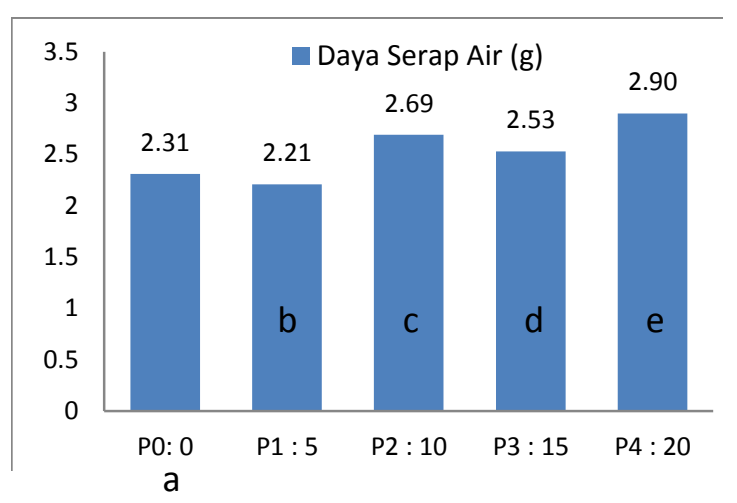

Keterangan: Notasi yang berbeda menunjukkan adanya perbedaan yang signifikan $(\alpha=0,05)$

Gambar 3. Daya Serap Air Tepung Ubi Jalar Kuning

Gambar 3 menunjukkan bahwa perlakuan metode blanching uap mempengaruhi daya serap air tepung ubi jalar kuning. Hasil analisis statistik One-Way Anova pada tingkat kepercayaan 95\% menunjukkan bahwa taraf perlakuan metode blanching berpengauh signifikan $(\mathrm{p}=0,000)$. Lebih lanjut, analisis statistik Duncan Multiple Range Test menunjukkan bahwa daya serap air tepung ubi jalar kuning pada masingmasing taraf perlakuan metode blanching (P0, P1, P2, P3 dan P4) menunjukkan adanya perberbedaan yang signifikan.

Perlakuan blanching uap dengan menggunakan rentan waktu yang berbeda menghasilkan daya serap air yang meningkat. Hal ini disebabkan kadar air tepung ubi jalar kuning pada tahap perlakauan blanching uap menghasilkan kadar air yang relatif rendah yang menyebabkan daya serap air tepung ubi jalar kuning semakin tinggi. Menurut Winarto (2008) bahwa bahan yang di blanching menggunakan uap air akan memiliki kadar air yang lebih rendah serta daya serap air yang tinggi dibandingkan dengan bahan yang diblanching dengan media air mendidih. Semakin tinggi daya serap air tepung ubi jalar kuning, maka semakin besar kemampuan tepung ubi jalar kuning untuk homogenisasi dengan adonan tepung ketika dicampur dengan air (Asgar dan Musaddad, 2006).

Perlakuan tepung ubi jalar dengan suhu pengeringan $70^{\circ} \mathrm{C}$ relative mengahasilkan daya serap air yang lebih tinggi. Winarno (1997) menyatakan bahwa suhu pengeringan yang rendah, panas yang diterima oleh bahan hanya dapat menguapkan sebagian air yang ada di permukaan, sehingga penurunan kadar air bahan relatif kecil.

\section{Sifat Fisik (Densitas Kamba)}

Densitas kamba merupakan berat bahan dalam volume tertentu termasuk volume udara yang ada pada ruang antar bahan, dinyatakan dalam g/ml. Menurut Winata (dalam Honestin, 2007), densitas 
kamba dipengaruhi oleh ukuran partikel, sifat bahan, komposisi bahan dan mungkin pula dipengaruhi oleh degradasi molekul-molekul dalam bahan akibat adanya pengolahan.

Densitas Kamba tepung ubi jalar kuning berkisar antara 0,53-0,79 g/ml. Densitas Kamba tepung ubi jalar kuning tertinggi terdapat pada taraf perlakuan blanching uap dengan waktu 20 menit yaitu $0,79 \mathrm{~g} / \mathrm{ml}$, sedangkan densitas kamba terendah terdapat pada taraf perlakuan tanpa blanching uap dengan yaitu $0,53 \mathrm{~g} / \mathrm{ml}$, sebagaimana disajikan pada Gambar 4.

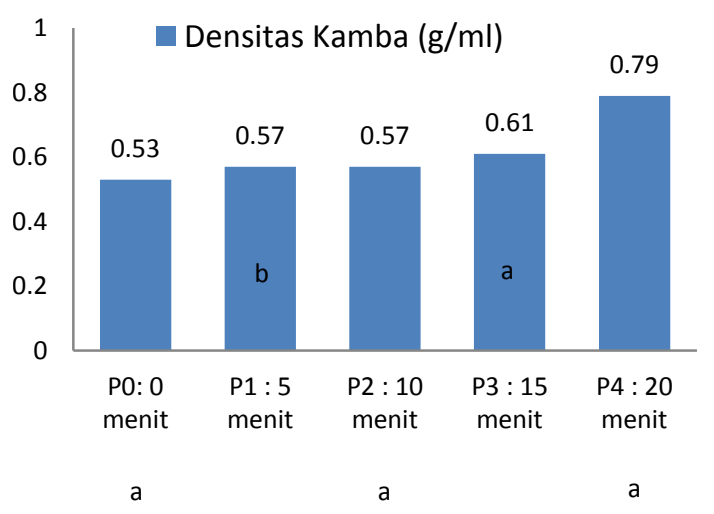

Keterangan: Notasi yang berbeda menunjukkan adanya perbedaan yang signifikan $(\alpha=0,05)$

Gambar 4. Densitas Kamba Tepung Ubi Jalar Kuning

Gambar 4. menunjukkan bahwa perlakuan metode blanching uap mempengaruhi densitas kamba tepung ubi jalar kuning. Hasil analisis statistik One-
Way Anova pada tingkat kepercayaan 95\% menunjukkan bahwa taraf perlakuan metode blanching berpengauh signifikan ( $\mathrm{p}=0,001)$. Pada uji lanjut analisis statistik Duncan Multiple Range Test menunjukkan bahwa densitas kamba tepung ubi jalar kuning pada semua taraf perlakuan, P1 menunjukan perbedaan yang signifikan dengan $\mathrm{P} 0, \mathrm{P} 2$, P3 dan P4.

Taraf perlakuan tanpa blanching menghasilkan densitas kamba relatif rendah dibandingkan dengan densitas kamba tepung ubi jalar kuning dengan perlakuan blanching uap dengan waktu yang berbeda-beda. Taraf semua perlakuan blanching uap menghasilkan densitas kamba tepung ubi jalar kuning yang berbeda-beda. Semakin lama waktu blanching yang dilakukan, semakin tinggi densitas kamba tepung ubi jalar kuning yang dihasilkan. Hal ini disebabkan kadar air yang dihasilkan oleh tepung ubi jalar kuning menurun, daya serap yang dihasilkan meningkat sehingga mengakibatkan densitas kamba yang dihasilkan relatif meningkat dan memiliki porositas yang meningkat pula.

Densitas kamba dari berbagai produk bubuk umumnya berkisar antara 0,30-0,80 g/mL (Wirakartakusumah et al., 1992). Semakin tinggi densitas kamba 
menunjukkan produk semakin ringkas atau padat. Menurut Husain (2008), kadar air tepung yang rendah disebabkan besar volume air yang menguap pada saat pengeringan, mengakibatkan semakin rendah kadar air yang terbentuk maka semakin kecil volume butiran tepung sehingga makin besar densitas kamba yang dihasilkan.

\section{Randemen}

Rendemen tepung ubi jalar kuning berkisar antara 47,0 - 59,9\%. Rendemen tepung ubi jalar kuning tertinggi terdapat pada taraf perlakuan blanching uap dengan waktu 20 menit yaitu 59,9\%, sedangkan rendemen terendah terdapat pada taraf perlakuan tanpa blanching uap dengan yaitu $47 \%$, sebagaimana disajikan pada Gambar 5.

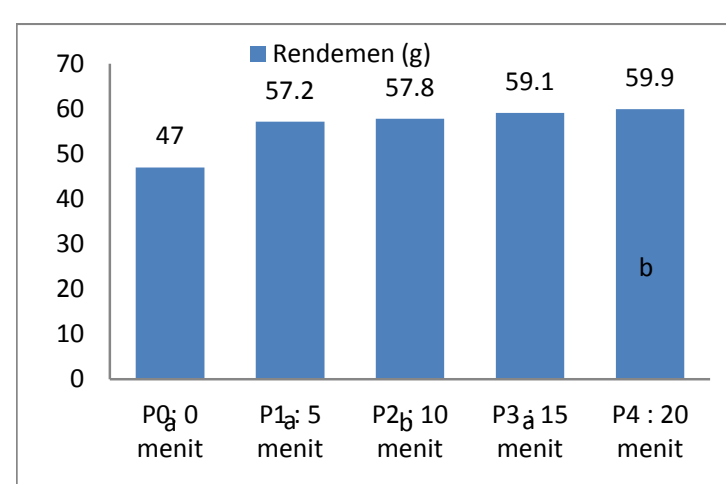

Keterangan: Notasi yang berbeda menunjukkan adanya perbedaan yang signifikan $(\alpha=0,05)$
Gambar 5. Rendemen Tepung Ubi Jalar Kuning

Gambar 5 menunjukkan bahwa perlakuan metode blanching uap mempengaruhi rendemen tepung ubi jalar kuning. Hasil analisis statistik One-Way Anova pada tingkat kepercayaan 95\% menunjukkan bahwa taraf perlakuan metode blanching berpengauh signifikan $(\mathrm{p}=0,001)$. Dan uji lanjut analisis statistik

\section{Duncan Multiple Range Test} menunjukkan bahwa rendemen tepung ubi jalar kuning pada semua taraf perlakuan menunjukan perbedaan yang signifikan antara P2 dengan P0, P1, P3 dan P4.

Taraf perlakuan dengan blancing uap dengan rentan waktu yang berbeda menghasilkan rendemen tepung ubi jalar kuning yag relatif lebih tinggi dibandingkan dengan taraf perlakuan tanpa blanching. Hal ini disebabkan uap air lebih mudah masuk kedalam jaringan ubi jalar kuning untuk merusak jaringan, kemudian pori-pori ubi jalar kuning akan terbuka lebar sehingga memudahkan laju penguapan air yang terdapat dalam ubi jalar kuning. Faktor lain yang mempengaruhi rendemen adalah kadar air dimana sejalan dengan penelitian. Asgar dan Musaddad (2006) menyatakan bahwa rendemen tepung hasil blanching uap lebih tinggi daripada 
rendemen tepung hasil blanching air. Hal ini dipengaruhi oleh laju penguapan air ubi jalar kuning pada perlakuan blanching uap lebih tinggi dibandingkan dngan laju penguapan air ubi jalar kuning yang di blanching air.

\section{KESIMPULAN}

Lama blanching uap memberikan pengaruh yang signifikan terhadap kadar betakaroten, kadar air, daya serap air, densitas kamba dan rendemen tepung ubi jalar kuning.

Berdasarkan hasil uji kimia dan uji fisik maka didapatkan bahwa perlakuan terbaik adalah yang dilakukan dengan blanching uap selama 20 menit dengan suhu pengeringan $70^{\circ} \mathrm{C}$.

\section{DAFTAR PUSTAKA}

Anggraini, A. A. (2013). Formulasi Labu Kuning (Curcubita moscehata Duch.) dan Kecambah Kacang Hijau (Phaseolus radius) terhadap Kualitas Fisik, Kadar Zat Gizi, dan Mutu Organoleptik Tepung Komposit Muffin Pumbean. Karya Tulis Ilmiah : Program Studi Diploma III Gizi, Poltekkes Kemenkes, Malang.

AOAC (1995) Official Method of Analysis of The Association of Official gricultural Chemistry (Proximate Analysis). Association of Official Analytical Chemistry.

Apriliyanti, T. (2010). Kajian Sifat Fisikokimia dan Sensori Tepung
Ubi Jalar Ungu (Ipomoea Batatas Blackie) dengan Variasi Proses Pengeringan. Skripsi : Jurusan/Program Studi Teknologi Hasil Pertanian. Universitas Sebelas Maret, Surakarta.

Apriyantono, A., D. Fardiaz, N. L. Sedarnawati dan S. Budiyanto. (1989). Analisa Pangan. Pusat Antar Universitas Pangan dan Gizi Institut Pertanian Bogor.

Asgar dan Musaddad. (2006). Optimalisasi Cara, Suhu dan Lama Blansing sebelum Pengeringan pada Wortel. Bal. Penel. Ilmu dan Teknologi Pangan. Jurnal J.Hort. Vol. 14. (2). Bogor.

BPS. (2015). Statistik Indonesia 2013 (ProduksiUmbi-umbian di Indonesia). Jakarta.

Estiasih dan Ahmadi. (2009). Teknologi Pengolahan Pangan. Bumi Aksara, Jakarta.

Honestin, T. (2007). Karakterisasi Sifat Fisikokimia Tepung Ubi Jalar (Ipomoea Batatas). Skripsi : Fakultas Teknologi Pertanian. IPB, Bogor.

Kemal, N.N dkk. (2013). Analisis Kandungan $\beta-$ Karoten dan Vitamin C dari Berbagai Varietas Ubi Jalar (Ipomoea Batatas).Jurnal Indonesia Chimica Acta. Makassar

Muchtadi, T. (1992). Petunjuk Labratorium Ilmu Pengetahuan Bahan Pangan. IPB, Bogor.

Muchtadi, T. (1997). Teknologi ProsesPengolahan Pangan. IPB, Bogor

Hussain S, Anjum FM, Butt MS, Sheikh MA (2008) Chemical composition and functional properties of flax- 
seed (Linum sitatissimum) flour. Sarhad J Agric 24(4): 649-653.

Puranti, P. D. (2012). Pengaruh Metode Blanching dan Suhu Penepungan Terhadap Kadar Beta Kroten dan Sifat Fungsional Tepung Labu Kuning (Curcubita moscehata). Karya Tulis llmiah : Program Studi DIII Gizi. Poltekkes Kemenkes, Malang.

Reifa. (2005). Ubi Jalar Sehatkan Mata dan Jantung, serta Mencegah Kanker. Majalah Kartini Nomor: 2134 Hal.148.

Riskesdas. (2007). Riset Kesehatan Dasar. Kementerian Kesehatan Republik Indonesia, Jakarta.

Riskesdas. (2013). Riset Kesehatan Dasar. Kementerian Kesehatan Republik Indonesia, Jakarta.

Rukmana, R. (1997). Ubi Jalar. Budidaya dan Pasca Panen. Kanisius, Yogyakarta.
Septiani, d. dkk. (2015). Uji Karakteristik Fisik, Kimia dan Organoleptik Tepung Umbi Suweg (Amorphophalluscampanulatus B) Sebagai Bahan Pangan Alternatif. Jurnal Bioproses Komoditas Tropis, Vol.3 No.1. Malang

Winarno, F.G. dan Jenie, S.L. (1974). Dasar Pengawetan, Sanitasi dan Peracunan. Departemen Teknologi Hasil Pertanian, Fatemeta, IPB. Bogor.

Winarno, F.G. dkk. (1980). Pengantar Teknologi Pangan. Gramedia Pustaka Utama, Jakarta.

Winarno, F.G . (1997). Kimia Pangan dan Gizi. Gramedia Pustaka Utama, Jakarta

Wirakartakusumah MA, A Kamarudin, AM Syarif (1992) Sifat fisik pangan. Depdikbud PAU Pangan dan Gizi. PT Gramedia. Jakara 